American Journal of Economics and Business Administration 2 (1): 64-72, 2010

ISSN 1945-5488

(C) 2010 Science Publications

\title{
Marketing Strategies in Port Industry: An Exploratory Study and a Research Agenda
}

\author{
${ }^{1}$ Angelos M. Pantouvakis, ${ }^{1}$ C.I. Chlomoudis and ${ }^{2}$ Athanasios G. Dimas \\ ${ }^{1}$ Department of Maritime Studies, University of Piraeus, Piraeus, Greece \\ ${ }^{2}$ Department of Business Administration of Food, University of Ioannina, Ioannina, Greece
}

\begin{abstract}
Problem statement: Market globalization increases demand and the competition between firms. Ports as basic figurative nodes cannot remain separate from this change. Technological improvements, the increased demand of marine transports, the demand for new, bigger and more specialized vessels, has increased the competition among ports. Approach: In this competitive environment business mistakes may be proved fatal and marketing strategies arise as a means for differentiation. As such, modern ports suffer both from internal and external pressures. On the one hand, they need to exhibit management competency in the pursuit of suitable strategy and in the allocation of scarce resources. On the other, they no longer enjoy the freedom of a monopoly and therefore face a completely competitive market. Results: The selection of a suitable strategy is important for ports wishing to improve their financial results. The better financial capability for a firm means investing in the constantly changing shipping market. Economic prosperity also adds value to a firm that uses suitable marketing strategies to satisfy its customers. Conclusion: The present richer examined two alternative strategies-profit maximization and revenue maximization-and explores the factors that influence the application of these two strategies in the port industry. Data from 18 European ports were examined by multiple step-wise regression. The results proved the diversity of the two applications.
\end{abstract}

Key words: Profit maximization strategy, revenue maximization strategy, ports

\section{INTRODUCTION}

The development of global trade, combined with market globalization, has brought about significant changes in land, air and sea transports. Sea transports now account for $90 \%$ of total transports and constitute a critical part of transport policies, especially in the European Union as more than $90 \%$ of the EU's external trade and some $43 \%$ of its internal trade is transported by sea (Chlomoudis et al., 2007). Ports as businesses combine an industry with services (Suykens, 1986) that pursue for increased effectiveness and productivity is continuous. Restructuring of old-fashioned organizations and management styles and/or privatization of all or some of the port activities (Tongzon, 1995) have been examined as potential remedy measures in this new era (Pallis and Tsiotsis, 2008).

Ports are the main part of the sea transport system as "the basic means to satisfy sustainable mobility" (Chlomoudis, 2006). In recent years, the structure and operation of ports has become adapted to the needs and demands of combined transports. These needs that focus on rapid and effective cargo management, actual port product development, adaptation to the new conditions of port production organization and the regulatory and institutional framework at an international level, have led to a complete change in port goals and character. Technological progress and increased demand for sea transport generate the need for investments and new infrastructures at ports. Together with infrastructure development, ports faced with an intensive competition offer now a wide range of services in terms of the quantities and varieties of cargos managed daily, the types of vessels anchored, the connection to land transports, the storage and other additional services (Roll and Hayuth, 1993) and valueadded services.

The delivery of these services requires the use of both classic contributors (land, work and capital) and the level of technology, cooperation with other companies of the whole transport system (door to door) and the adaptation of port management to the new conditions (Roll and Hayuth, 1993). The need for a systematic process that will include the development of strategies to achieve goals and distribute resources to implement these strategies, based on which every port will be able to deal with market changes, is now 
apparent (Siomkos, 2004). The strategic planning of ports includes port marketing, which is of major importance because of its responsiveness to the continuously changing needs of the new free market and which is the linchpin between the internal and external environments of the port business.

The goals of ports-businesses, according to classical economic theory, are either to increase total revenue or to increase profits (Brown and Laverick, 1994). The selection of one of the two goals has been extensively explored in literature (Baumol, 1959; Amihud and Kamid, 1979). These goals are mainly associated with the way in which owners or managers control their ports (Amihud and Kamid, 1979) and/or with the short-term achievement of maximum efficiency (Marris, 1964) or the concept that the main goal of businesses cannot be restricted to the maximisation of profits (Brown and Laverick, 1994; Baumol, 1959).

It is therefore evident that the selection of one of the two goals can differentiate the strategy followed by the business. The obvious question is whether and to what extent these two goals generate or require different marketing policies, especially in the port industry.

This study begins with a brief description of port industry and the structural changes it has undergone in the recent years and continues with a literature review of theories describing the differences between the two strategies that businesses can adopt. Then, the methodology and research data analysis are presented.

\section{Conceptual background:}

Defining business' performance: The main purposes of port businesses today are success and excellence. Success is a multidimensional construct, (Porter, 1980) and so is excellence (Speed and Smith, 1993). Business success and excellence in port industry were associated with business performance from 1980-2000. The performance of a business (Speed and Smith, 1993) is not a one-dimensional construct and cannot be measured using only one factor (e.g., product production or service delivery). The performance of a business also includes other variables (Wright, 1985), such as consumer-user satisfaction, provided service quality, operating profit, management style and market share (Anderson et al., 1994), user-customer retention (Rust and Zahorik, 1993), efficiency (Rust et al., 1995) market share and cost effectiveness (Berger, 1995). More specifically, business performance defined (Sink and Tuttle, 1989) as a complex interdependence among efficiency, effectiveness, quality, productivity, working conditions quality, innovation and profitability.
Performance of service companies contains 6 dimensions (Fitzerald et al., 1991), based on competition, business economic performance, offered services quality, productivity, innovation and business flexibility. The first two dimensions, (Fitzerald et al., 1991) are associated with the strategy adopted by the business and the remaining four determine the success achieved by the business operation.

The complexity and the great variety of factors affecting the performance of a business make its measurement difficult. Performance can be measured with many factors using multiple inputs and outputs. These factors are not always the same, but they depend on specific dimensions, such as the form of business ownership, the intensity of competition, government intervention in the market, the degree of political accountability or political control, the style of management and business organizational structure (Fitzerald et al., 1991).

As previously mentioned, performance is a complex interdependence among many factors, one of which is productivity. In the port industry, productivity (e.g., how many tons of cargo are stevedored) (Tongzon, 1995), is used to measure port performance. Total port productivity, depends on a series of factors such as geographical position, fees, general economic activity and the efficiency of the terminal (Tongzon, 1995). Ports based on their older character-businesses owned by the state and being subject to state restrictions-are interested in maximizing their productivity on the condition of reaching a specific total revenue (Tongzon, 1995). Thus, to achieve revenue maximization every port should follow a specific strategy. The structural changes that took place in ports during the last decades and changed the form of their ownership from state to private (Port of Antwerp, Port of Tallinn, Port of Helsinki, Port of Hamburg, Port of Dublin), even though they did not change the original strategy of ports to maximize their productivity, changed the strategy to maximize revenue into a strategy to maximize profits in order to satisfy the demands of shareholders (Tongzon, 1995). These two strategies are not the same and require a different policy on the part of the companies to achieve the desired results (Baumol, 1959; Dunshire et al., 1991).

Defining inputs and outputs in the port industry: Management science has brought to light the idea of measuring efficiency (Charnes et al., 1994), where performance depends on the best production unit taking into account a series of multiple inputs and outputs in the production process. Inputs and outputs, (Roll and Hayuth, 1993), characterize the production process and 
the type and level of service offered by the business. A series of inputs is necessary in every business during the production process to generate outputs. The most obvious inputs used by every business in its production process are the three production contributors: Land, work and capital. However, there are also other factors affecting business efficiency (Altubas et al., 2001).

Based on these approaches, profit maximization could depend on the difference in the fees for the external and internal services offered by a business.

In the port industry, many academics have examined performance and efficiency. In their research they have used a series of inputs, which are the number of people employed in a port (Barros, 2003; Barros and Athanassiou, 2004; Roll and Hayuth, 1993), the number of gantry cranes (Cullinane et al., 2004), the area occupied by the terminal (Cullinane et al., 2004; Wang and Cullinane, 2006), the fixed assets of the business (Barros, 2003; Cullinane and Song, 2003; MelendezHidalgo et al., 2007), operating cost (Barros, 2005; 2006), depreciations (Martinez-Budria et al., 1999), the total number of piers in a port (Cullinane et al., 2004).

In addition, the literature on the port industry refers to a series of outputs, which are total revenue (Cullinane and Song, 2003; Martinez-Budria et al., 1999; Liu, 1995; Park and De, 2004) total TEUs managed by the port (Cullinane et al., 2004; Liu, 1995), total tons stevedored at the port (Barros, 2003; Barros and Athanassiou, 2004; Martinez-Budria et al., 1999; Park and De, 2004; Roll and Hayuth, 1993) total vessel traffic (Barros, 2003; Barros and Athanassiou, 2004), passengers transported (Barros, 2006; Coto Millan et al., 2000), tankers and dry bulk vessels (Barros, 2006).

\section{Research hypotheses:}

Alternative strategies Profit maximization strategy and revenue maximization strategy: Businesses follow several marketing strategies to achieve their purposes (success and excellence). Marketing strategies can be long- or short-term depending on the goals of the business (Baker et al., 1988; Doyle et al., 1992), strategies of target-market identification and segmentation (Hooley and Jobber, 1986), strategies of competitor identification (Doyle et al., 1992), strategies of competitive advantage creation (Baker et al., 1988) and pricing strategies (Doyle et al., 1992; Hall, 1980).

Modern businesses also adopt alternative strategies, such as profit maximization or revenue maximization (Yarrow, 1973). Many theories have been developed regarding these two strategies and the differences in the views of owners and managers about the strategy that businesses should follow at a given time (Baumol, 1959).
Classical economic theory argues that the purpose of businesses is profit maximization. In contrast, modern management theory suggests that the purpose of today's businesses is revenue maximization. Although Baumol (1959) believes that the main strategy of businesses should be revenue maximization, he recognizes the need to achieve satisfactory profits. Baumol (1959) argue that the strategy of revenue maximization is mainly a requirement of modern management that is mostly interested in increasing the company's size. At the same time, the company's owner is mostly interested in profit maximization (Baumol, 1959). Moreover, Marris (1964) supports that business success is achieved through the company's continuous development and more specifically through revenue maximization. The strategy of revenue maximization reflects managers' efforts to reduce the dangers and risks of their actions (Amihud and Kamid, 1979). It has been theoretically and empirically proven (Dunshire et al., 1991) that managers prefer strategies that will yield results with less risk than business owners. If managers select a strategy of profit maximization, then in a supposed financial disorder this strategy will lead to extremely reduced profits. However, if managers select a strategy that produces maximum profit (just offers a satisfactory rate of profit) the company's shareholders will be satisfied. Using this strategy, they will be able to maintain a satisfactory level of profits through the years and shape more appropriate strategies for the future. Thus, the strategies of profit maximization and revenue maximization are not the same.

In the port industry, each port should implement appropriate management and marketing policies. The strategy of revenue maximization has been more widespread among the ports that were under governmental supervision, since their main aim was to maximize service production, thus their revenue, without being interested in profit making (Talley, 2006). In this case, total revenue could be equal to total costs, thus giving no profit margin or they could have a deficit and be subsidized by the state (Talley, 2006).

In previous research carried out on port industry regarding port performance and efficiency measurement, total revenue constitutes the outputs of the use of inputs in service production (Cullinane and Song, 2003; Martinez-Budria et al., 1999; Liu, 1995; Park and De, 2004). According to researchers, the inputs used are the total cargo traffic in tons (Liu, 1995), the expenses for the staff and depreciations (Martinez-Budria et al., 1999), the fixed capitals of the business (Cullinane and Song, 2003) and the number of vessels that are stevedored at a port (Park and De, 2004). 
On the contrary, from what we know today, total profits have not been used to measure port efficiency. Of course, other researchers (Wilder, 1981), state that total profits of ports directly depend on ship congestion at the terminal, but the profit maximization of ports is affected by the power of shipping companies. Moreover, Siomkos (2004) suggests that profits are determined by the existing technology and other factors (raw materials, capitals, workforce) and the characteristics of competition.

On this basis, the following research hypotheses are formulated:

H1: The strategy of profit maximization that a port can follow is different from the strategy of revenue maximization

H2: Total revenue is a multi-dimensional construct that depends on certain financial and not financial variables

H3: Total profit is a multi-dimensional construct that depends mainly on certain financial and not financial variables not necessarily the same as those influencing the revenues

\section{MATERIALS AND METHODS}

Data analysis: The initial aim of this research was to examine a pool of 60 European ports. However certain port authorities have neither published an audited Profit and Loss account statement nor they have used compatible accounting practices. This way ports like Bremerhaven, Algeciras, Felixtowe, Gioia Tauro, Le Havre, Genoa, Zeebrugge, Southampton, Constanza have been excluded from further analysis. A final pool of 18 ports was finally selected satisfying the above said requirements. These ports are presented in Table 1.

Variables used in this study comply in general with two criteria: The first has to do with the activities of the port per se. Research supports that activities of a port may be decomposed to seven handling stages: (1) passage of the ship through the approach channel up to the quay; (2) transit storage; (3) loading the cargo on to land transport; (4) discharge of the cargo from the ship's hold to the quay; (5) moving the cargo from transit to the loading platform; (6) moving the cargo from the quay to transit storage; (7) departure of land transport from the port area (Lopez and Poole, 1998). The second criterion follows a rather more mechanisticexploratory-way based on availability of data and validity of the research instrument (Cullinane and Song, 2003).
Table 1: Selected ports

\begin{tabular}{llll}
\hline Belgium & Antwerp & Portugal & Sines \\
Germany & Hamburg & Finland & Helsinki \\
Estonia & Tallinn & Finland & Kotka \\
Ireland & Dublin & Finland & Turku \\
Greece & Piraeus & Sweden & Malmo \\
Greece & Thessaloniki & United Kingdom & Belfast \\
Spain & Malaga & Netherlands & Amsterdam \\
Spain & Barcelona & Spain & Bilbao \\
Netherlands & Rotterdam & Slovenia & Koper \\
\hline
\end{tabular}

Therefore two set of variables were introduced for consideration. The first set of variables examines the financial status of the selected port whilst the second provides a more productive role of the port.

The first part of variables includes financial data to depict the bottom line situation of any port authority. Although certain considerations have been arisen for the data compatibility every effort has been made to transform the data to a attuned way. Notes on accounts have been induced in the analysis and certain provisions have been made for similarity reasons. Variables include: Tangible fixed assets (Barros, 2003) representing the existing available infrastructure (land and building, machinery and equipment, fixtures and fittings and vehicles) of the port. Note that this variable encapsulates investments made at a previous stage of development. To capture the pace of investment it has been decided to incorporate depreciation (MartinezBudria et al., 1999) as a further financial measure. In addition, operating expenses (Barros, 2005) are examined to estimate the cost side of the equation. Nevertheless wages and salaries were not included to cover for diversified operating statuses-e.g., port operators are not usually included in this part of this $\mathrm{P}$ and $\mathrm{L}$ account. Finally according to our main hypotheses of this study-to explore the possibility of the simultaneous existence of two distinct marketing strategies-profit and revenue maximization, operating profit and total turnover included in the analysis.

In the second set of variables the productive ability of the port is introduced and the role of the total port traffic is examined. Variables include the whole number of vessels approaching the port for loading or unloading activities (Barros and Athanassiou, 2004), divided in number of tankers, bulk carries and container ships (Barros, 2003). The importance of total port throughput or the port's capacity was examined by the total TEUs loaded or unloaded (Cullinane et al., 2004; Tongzon, 1995), total tons movement (Coto Millan et al., 2000; Liu, 1995) and total and by type of vessel Gross Registered Tonnage (tankers, bulk carries, container ships). This research also attempted to explore the rather neglected role of the passenger in the main port activities-as a means for profit or revenue generator-and included passenger and cruise passenger movements (Coto Millan et al., 2000). 
Am. J. of Economics and Business Administration 2 (1): 64-72, 2010

Table 2: Selected variables

\begin{tabular}{|c|c|c|c|c|c|c|c|c|c|c|c|c|c|c|c|c|}
\hline & $\begin{array}{l}\text { No. of } \\
\text { vessels } \\
\text { in general }\end{array}$ & $\begin{array}{l}\text { No. of } \\
\text { Tankers }\end{array}$ & $\begin{array}{l}\text { No. of } \\
\text { bulk } \\
\text { carriers }\end{array}$ & $\begin{array}{l}\text { No. of } \\
\text { container } \\
\text { ships }\end{array}$ & $\begin{array}{l}\text { Total } \\
\text { GRT }\end{array}$ & $\begin{array}{l}\text { GRT } \\
\text { tankers }\end{array}$ & $\begin{array}{l}\text { GRT } \\
\text { bulk } \\
\text { carriers }\end{array}$ & $\begin{array}{l}\text { GRT } \\
\text { container } \\
\text { ships }\end{array}$ & $\begin{array}{l}\text { Total } \\
\text { TEU }\end{array}$ & $\begin{array}{l}\text { Total } \\
\text { tons } \\
\text { in-out }\end{array}$ & $\begin{array}{l}\text { Passengers } \\
+ \text { cruise } \\
\text { passengers }\end{array}$ & $\begin{array}{l}\text { Tangible } \\
\text { fixed } \\
\text { assets }\end{array}$ & $\begin{array}{l}\text { Operating } \\
\text { profit }\end{array}$ & $\begin{array}{l}\text { Operating } \\
\text { expenses }\end{array}$ & Revenue & Depreciation \\
\hline$\overline{\text { Amsterda }}$ & 4758 & 1267 & 461 & 430 & 70895 & 18172 & 14510 & 15808 & 183360 & 56794000 & 13987000 & 472000000 & 29300000 & 70388619 & 99688619 & 16900000 \\
\hline Antwe & 15729 & 4047 & 12 & 3503 & 264641 & 36683 & 582 & 121900 & 6718196 & 151705000 & 8000 & 957024000 & 73544000 & 214205000 & 287749000 & 45900000 \\
\hline Barcelona & 9815 & 768 & 177 & 2153 & 216592 & 15143 & 2841 & 63047 & 2314581 & 38267000 & 1927000 & 1372818000 & 58033000 & 199609000 & 257642000 & 25347000 \\
\hline Belfast & & 437 & 66 & 200 & 71471 & 2470 & 1151 & 947 & 235902 & 13514000 & 1406000 & 233268941 & 18977719 & 18137183 & 37114902 & 5446920 \\
\hline Bilbao & 14 & 812 & 792 & 719 & 50485 & 20248 & 4625 & 6939 & 686870 & 36118000 & 121000 & 742809000 & 38873000 & 23212000 & 62085000 & 21176000 \\
\hline Dublin & 7287 & 490 & 508 & 1678 & 127424 & 3524 & 2288 & 9162 & 680679 & 20795000 & 1245000 & 217004000 & 25592000 & 40831000 & 66423000 & 8485000 \\
\hline Haml & 197 & 905 & & & 5247 & 10326 & 17006 & 153968 & 8878093 & & & & 5850 & 230233914 & 260769764 & 29341545 \\
\hline $\mathrm{H}$ & & 92 & 23 & & 0861 & 614 & 395 & & & & 0 & & & & & 11881467 \\
\hline Koper & 12 & 125 & 594 & 489 & 27486 & 2235 & 7275 & 6457 & 222049 & 15391000 & 1000 & 149277000 & 19953165 & 77410582 & 97363748 & 3970257 \\
\hline & & 221 & 13 & & 26002 & 1186 & 113 & & & & 12000 & & & & 34716000 & 6666000 \\
\hline Malaga & 1869 & 38 & 67 & 368 & 32844 & 310 & 1128 & 14550 & 452099 & 6049000 & 286000 & 9008668 & -643728 & 16019455 & 14196466 & 73557322 \\
\hline$M$ & & & & & 48031 & & 50 & 637 & & & & & & & & 3693597 \\
\hline Piraeus & 30568 & 809 & 13 & 1565 & 198148 & 6372 & 500 & 30849 & 1412554 & 19948000 & 11539 & 192529311 & 17718117 & 126419070 & 144137187 & 9143381 \\
\hline Rotterda & 70 & & 1092 & & 534630 & 128104 & 57785 & 179023 & 9575409 & 3535 & 504000 & 2290817000 & 174257000 & 281347000 & 455604000 & 83162000 \\
\hline Sines & 1351 & 974 & 54 & 263 & 29692 & 17686 & 3721 & 7848 & 121957 & 26934000 & 1000 & 70358726 & 3767580 & 30363185 & 34130756 & 72808370 \\
\hline & & & 31 & 441 & 126271 & & & & & & 64 & 460 & 467 & & 75285000 & 11973000 \\
\hline Thessal & 2732 & 581 & 559 & 618 & 20475 & 6182 & 2493 & 8692 & 355180 & 16358000 & & & 6887000 & 39060000 & 45947000 & 3649000 \\
\hline Turku & 3017 & 100 & 1 & 50 & 79659 & 520 & 2 & 298 & 20429 & 3926000 & 3620000 & 72658862 & 8575969 & 15548010 & 24123979 & 3900661 \\
\hline
\end{tabular}

Table 3: Correlations

\begin{tabular}{|c|c|c|c|c|c|c|c|c|c|c|c|c|c|}
\hline & $\begin{array}{l}\text { No. of } \\
\text { vessels in } \\
\text { general }\end{array}$ & $\begin{array}{l}\text { No. of } \\
\text { tankers }\end{array}$ & $\begin{array}{l}\text { No. of } \\
\text { bulk } \\
\text { carriers }\end{array}$ & $\begin{array}{l}\text { No of } \\
\text { container } \\
\text { ships }\end{array}$ & $\begin{array}{l}\text { Total } \\
\text { GRT }\end{array}$ & $\begin{array}{l}\text { GRT } \\
\text { tankers }\end{array}$ & $\begin{array}{l}\text { GRT } \\
\text { bulk } \\
\text { carriers }\end{array}$ & $\begin{array}{l}\text { Total } \\
\text { TEU }\end{array}$ & $\begin{array}{l}\text { Total tons } \\
\text { in-out }\end{array}$ & $\begin{array}{l}\text { Tangible } \\
\text { fixed } \\
\text { assets }\end{array}$ & $\begin{array}{l}\text { Operating } \\
\text { profit }\end{array}$ & $\begin{array}{l}\text { Operating } \\
\text { expenses }\end{array}$ & Revenue \\
\hline $\begin{array}{l}\text { No. of vessels in } \\
\text { general }\end{array}$ & & & & & $0.841^{* *}$ & & & & & & & & $0.717 * *$ \\
\hline No. of tankers & & & & & $0.862^{* *}$ & $0.964 * *$ & 0.824 & $0.780^{* *}$ & $0.963^{* *}$ & $0.822^{* *}$ & $0.914^{* *}$ & $0.743^{* *}$ & $0.845^{* *}$ \\
\hline No. of bulk carriers & & & & & & & $0.724 * *$ & & & & & & \\
\hline No of container ships & & & & & $0.770^{* *}$ & & & $0.969 * *$ & $0.785^{* *}$ & $0.759 * *$ & & $0.886^{* *}$ & $0.860 * *$ \\
\hline Total GRT & $0.841 * *$ & $0.862 * *$ & & $0.770 * *$ & & $0.843^{* *}$ & 0.759 & $0.823^{* *}$ & $0.893 * *$ & $0.886^{* *}$ & $0.923^{* *}$ & $0.849 * *$ & $0.927 * *$ \\
\hline GRT tankers & & $0.964 * *$ & & & $0.843^{* *}$ & & 0.913 & $0.720^{* *}$ & $0.955^{* *}$ & $0.851^{* *}$ & $0.929 * *$ & & $0.807^{* *}$ \\
\hline GRT bulk carriers & & $0.824 * *$ & $0.724 * *$ & & $0.759^{* *}$ & $0.913 * *$ & & $0.707^{* *}$ & $0.903 * *$ & $0.789^{* *}$ & $0.833^{* *}$ & & $0.749^{* *}$ \\
\hline GRT container ships & & $0.797 * *$ & & $0.959 * *$ & $0.844^{* *}$ & $0.742 * *$ & 0.723 & $0.993 * *$ & $0.879 * *$ & $0.839 * *$ & $0.763^{* *}$ & $0.943^{* *}$ & $0.937 * *$ \\
\hline Total TEU & & $0.780^{* *}$ & & $0.969^{* *}$ & $0.823^{* *}$ & $0.720 * *$ & $0.707 * *$ & & $0.871^{* *}$ & $0.807^{* *}$ & $0.743^{* *}$ & $0.911 * *$ & $0.907 * *$ \\
\hline Total tons in-out & & $0.963^{* *}$ & & $0.785 * *$ & $0.893^{* *}$ & $0.955^{* *}$ & $0.903^{* *}$ & $0.871 * *$ & & $0.881 * *$ & $0.934 * *$ & $0.797 * *$ & $0.892 * *$ \\
\hline Tangible fixed assets & & $0.822^{* *}$ & & $0.759 * *$ & $0.886^{* *}$ & $0.851 * *$ & $0.789 * *$ & $0.807 * *$ & $0.881 * *$ & & $0.936^{* *}$ & $0.842 * *$ & $0.925 * *$ \\
\hline Operating profit & & $0.914 * *$ & & & $0.923^{* *}$ & $0.929 * *$ & $0.833^{* *}$ & $0.743^{* *}$ & $0.934 * *$ & $0.936^{* *}$ & & $0.746 * *$ & $0.880^{* *}$ \\
\hline Operating expenses & & $0.743^{* *}$ & & $0.886^{* *}$ & $0.849^{* *}$ & & & 0.911 & $0.797 * *$ & $0.842 * *$ & $0.746^{* *}$ & & $0.973^{* *}$ \\
\hline Revenue & $0.717 * *$ & $0.845^{* *}$ & & $0.860 * *$ & $0.927^{* *}$ & $0.807 * *$ & $0.749 * *$ & $0.907 * *$ & $0.892 * *$ & $0.925^{* *}$ & $0.880 * *$ & $0.973^{* *}$ & \\
\hline
\end{tabular}

**: Correlation is significant at the 0.01 level (2-tailed). *: Correlation is significant at the 0.05 level (2-tailed)

As the EU initiative for the short sea shipping (Maritime Transport Policy, 2007) comes into power from 1999 the impact and the benefits of the port passenger industry seems rather a totally unexplored area with few studies addressing the issue in the literature (Pantouvakis et al., 2008).

The relevant data are presented in Table 2.

Data analysis: Research data were initially analyzed using the bivariate correlation process and the calculation of the Pearson correlation coefficient in order to measure the strength of the relationship among the variables used in research. It is clear that a high correlation coefficient is expected between variables (inputs-outputs) and a lower correlation coefficient among inputs. In this way, it is expected to numerically confirm the relationship between inputs and outputs that is suggested in literature. The correlations are presented in Table 3.

Table 3 provides robust evidence for the nature and the strength of the relationships between variables by attending the relevant correlation coefficients. The higher and the closer to 1 the Pearson correlation coefficient is, the stronger the correlation of one variable with another is (Field, 2005).
It should therefore be noted that:

- Total profits present a high correlation with the number of tankers and the total tons stevedored at a port. They also present a high correlation with the fixed assets of the business

- Total revenue on the other hand present a high correlation with the total volume of containers stevedored at the ports, with the total TEUs, with the total tons of all types of cargo and with the fixed assets of the business

To confirm the hypotheses of the research we used the stepwise regression method. Stepwise regression was applied twice to draw conclusions and operating profit was used as a dependent variable in the first case and in the second case the revenue of ports was used as a independent variables. Dependent variable and the rest variables in Table 2 were used as independent variables.

In the first case, operating profit was used as a dependent variable and the rest variables in Table 2 as the results are presented in the Table 4 and 5. 
Am. J. of Economics and Business Administration 2 (1): 64-72, 2010

Table 4: R-adjusted $\mathrm{R}^{2}$ : Model summary

\begin{tabular}{|c|c|c|c|c|c|c|c|c|c|c|}
\hline \multirow[b]{2}{*}{ Model } & \multirow[b]{2}{*}{$\mathrm{R}$} & \multirow[b]{2}{*}{$\mathrm{R}^{2}$} & \multirow[b]{2}{*}{$\begin{array}{l}\text { Adjusted } \\
\mathrm{R}^{2}\end{array}$} & \multirow[b]{2}{*}{$\begin{array}{l}\text { Std. Error of } \\
\text { the estimate }\end{array}$} & \multicolumn{5}{|c|}{ Change statistics } & \multirow[b]{2}{*}{$\begin{array}{l}\text { Durbin- } \\
\text { Watson }\end{array}$} \\
\hline & & & & & $\begin{array}{l}\mathrm{R}^{2} \\
\text { change }\end{array}$ & $\begin{array}{l}\mathrm{F} \\
\text { change }\end{array}$ & df1 & df 2 & $\begin{array}{l}\text { Sig. F } \\
\text { change }\end{array}$ & \\
\hline 2 & $0.970(\mathrm{~b})$ & 0.940 & 0.932 & 10503.599 & 0.064 & 16.053 & 1 & 15 & 0.001 & 1.808 \\
\hline
\end{tabular}

Predictors: (Constant), Tangible fixed assets; Predictors: (Constant), tangible fixed assets, No. of tankers

Table 5: Coefficients (a)

\begin{tabular}{|c|c|c|c|c|c|c|c|c|}
\hline \multirow{2}{*}{\multicolumn{2}{|c|}{ Model }} & \multicolumn{2}{|c|}{ Unstandardized coefficients } & \multirow{2}{*}{$\begin{array}{l}\text { Standardized } \\
\text { coefficients } \\
\text { Beta }\end{array}$} & \multirow[b]{2}{*}{$\mathrm{t}$} & \multirow[b]{2}{*}{ Sig. } & \multicolumn{2}{|c|}{ Collinearity statistics } \\
\hline & & $\mathrm{B}$ & Std. Error & & & & Tolerance & VIF \\
\hline \multirow[t]{3}{*}{2} & (Constant) & 3994.539 & 3225.511 & & & 1.238 & 0.235 & \\
\hline & Tangible fixed assets & 0.038 & 0.008 & 0.570 & 5.124 & 0.000 & 0.324 & 3.086 \\
\hline & No. of tankers & 10.045 & 2.507 & 0.445 & 4.007 & 0.001 & 0.324 & 3.086 \\
\hline
\end{tabular}

Dependent variable: Operating profit

Table 6: R-adjusted $\mathrm{R}^{2}$ model summary (d)

\begin{tabular}{|c|c|c|c|c|c|c|c|c|c|c|}
\hline \multirow[b]{2}{*}{ Model } & \multirow[b]{2}{*}{$\mathrm{R}$} & \multirow[b]{2}{*}{$\mathrm{R}^{2}$} & \multirow[b]{2}{*}{$\mathrm{R}^{2}$} & \multirow[b]{2}{*}{$\begin{array}{l}\text { Adjusted } \\
\text { the estimate }\end{array}$} & \multirow[b]{2}{*}{$\begin{array}{l}\text { Std. Error of } \\
\text { change }\end{array}$} & \multicolumn{5}{|c|}{ Change statistics } \\
\hline & & & & & & $\begin{array}{l}\mathrm{R}^{2} \\
\text { change }\end{array}$ & $\begin{array}{l}\mathrm{F} \\
\mathrm{df} 1\end{array}$ & df2 & $\begin{array}{l}\text { Sig. F } \\
\text { change }\end{array}$ & $\begin{array}{l}\text { Durbin- } \\
\text { Watson }\end{array}$ \\
\hline 3 & 974(c) & 0.948 & 0.937 & 29855.170 & 0.024 & 6.604 & 1 & 14 & 0.022 & 2.742 \\
\hline \multicolumn{11}{|c|}{$\begin{array}{l}\text { Predictors: (constant), GRT container ships; Predictors: (Constant), GRT container ships, tangible fixed assets; Predictors: (constant), GRT } \\
\text { container ships, tangible fixed assets, No. of vessels in genera; Dependent variable: Revenue }\end{array}$} \\
\hline \multicolumn{11}{|c|}{ Table 7: Coefficients (a) } \\
\hline \multirow[b]{2}{*}{ Model } & & & \multicolumn{2}{|c|}{ Unstandardized coefficients } & \multirow{2}{*}{$\begin{array}{l}\text { Standardized } \\
\text { coefficients } \\
\text { beta }\end{array}$} & \multirow[b]{2}{*}{$\mathrm{t}$} & \multirow{2}{*}{\multicolumn{2}{|c|}{ Sig. }} & & \\
\hline & & & $\mathrm{B}$ & Std. Error & & & & & Tolerance & VIF \\
\hline \multirow[t]{4}{*}{3} & (Constant) & & 22563.070 & 10511.228 & 2.190 & 0.050 & & & & \\
\hline & Total GRT & & 0.294 & 0.134 & 0.313 & 2.190 & & & 0.181 & 5.527 \\
\hline & Tangible $\mathrm{f}$ & ssets & 0.014 & 0.004 & 0.365 & 3.256 & & & 0.295 & 3.388 \\
\hline & TEU & & 0.071 & 0.027 & 0.353 & 2.570 & & & 0.196 & 5.111 \\
\hline
\end{tabular}

Dependent variable: Revenue

Table 4 shows that the two variables account for 93.2\% of total sample variance (Adjusted $\mathrm{R}^{2}=0.932$ ). There is also no problem of multicollinearity since the values of Tolerance and VIF are at quite a good level (Tolerance $>0.01$ and VIF $<10$ ) (Field, 2005). According to the results of Table 5 the variable "operating profits" depends on the tangible fixed assets of a port (e.g., facilities) and the number of tankers loading or uploading in a port:

$\mathrm{f}($ Operating Profit $)=4054.8+0.038$ (Tangible Fixed Assets $)$ +10.045 (Number of Tankers)

In the second case, stepwise regression was applied and total revenue was used as a dependent variable and the rest variables in Table 2 as independent variables. The results are presented in the Table 6 and 7 .

From the results of Table 6 the third model is proposed with three variables that account for $93.7 \%$ of total sample's variance. There is also no problem of multicollinearity, since the values of Tolerance and VIF are at quite a good level (Tolerance $>0.01$ and $\mathrm{VIF}<10$ )
(Field, 2005). According to the results as it seems from Table 7 the variable "total revenue" depends on total vessel gross registered tonnage, tangible fixed assets and total TEUs stevedored at the port:

$\begin{aligned} \mathrm{f}(\text { revenue })= & 22563.525+0.294(\text { total GRT })+0.014 \\ & (\text { TEU })+0.071(\text { Tangible fixed assets })\end{aligned}$ RESULTS AND DISCUSSION

The results provide robust evidence that the two strategies-profit and revenue maximization- are found to be distinct First due to the fact that various variables differently load to the stepwise regression and secondly because revenue although inserted has not finally included as profit predictor in all our regression models. A further interesting conclusion supports that no financial variables from the $\mathrm{P}$ and $\mathrm{L}$ account-such as operating costs and depreciations-may significantly influence the strategies' pursue. This contradicts the rather common notion that ports are cost centers and that by reducing expenses better results are expected. A 
better outcome is envisaged when the "sell" department functions well in every port and attracts new or retains the old customers.

Moreover, examining the two equations of stepwise regression, tangible fixed assets is a factor affecting total revenue and operating profits. It seems that past investments in fixed assets not only have return, but also contribute to the increased future productivity of ports. This leads to the conclusion that the investments in tangible fixed assets such as new terminals, storage areas and other equipment that were made in previous years by port authorities yield profits and revenue for ports. Another important outcome is that profits depend also on the number of tankers approaching a port contrarily with revenues that depend both on container transportation and on the total tonnage of the vessels. This assumption could be important for port managers as they could differentiate their strategy determination taking into account the environmental constraints applied in liquids freight transportation. Finally, both models do not accommodate the passengers' transport as a revenue or profit contributor. The low correlation coefficients identified as well the insignificances observed may support that in the total bulk of port operations passengers are the "sleeping giant". As their part in the process for the time momentum has not been sufficiently exploited and neither negative nor positive roles may be attributed to their participation perhaps a more rigorous approach to some future study may be required.

\section{CONCLUSION}

Ports as traditional transit points play an emerging role in the new global era. Maritime transportation literature emphasizes in this particular role of ports as transitional logistic points. Also the globalization of trade and the growth in sea transport have resulted in port traffic increases at an average of about $3 \%$ per year. Moreover, the technological improvements and rapidly growing Eastern markets have intensified the competition, impacting on port activities. New port infrastructures have been planned, improvements in port services have been designed and new maritime transport technologies have been applied, so that ports improve their efficiency and their services in order to compete with national and international competitors. These circumstances postulate the adoption of new marketing strategies, more competitive and targeted to the improvement in port financial state. Port managers forced to deal with new competitive environment by adopting strategies such as profit or revenue maximization in order to reach their goals.
This research, taking into account the results has concluded that two distinct strategies may be applied or used from relevant port authorities. Regarding profit or revenue maximization strategies port managers should adapt their tactics to the set goals and consequently adopt the most suitable marketing strategies. This study argues that one strategy may focus on profit maximization and this seems to be the case for of state owned and controlled companies. A second distinct strategy mainly focuses on revenue maximization and considers them as of major importance. This strategy suites more to the more risk averse controllers-as in the case of managers-who prefer size to profits. In a direct analogy one may assume that depending on control status (manager or port operator versus owner or port authority) one of the two strategies may be selected. The social contribution of every port is considered to be responsibility of the state and thus is not included in this study.

The two strategies examined in this research suggest ways that a port authority can increase its total revenue or profits. The adoption of either of these two strategies may improve ports' financial status and can therefore provide decision makers with better and more alternatives. Consequently, one may decide whether to proceed with investments and in what business section (liquid or bulk or container) or whether cost cut-offs appear as the most appropriate solution. New roles, changing market environments require flexible and decisive solutions and a clear eagerness on keeping customers satisfied (Notteboom, 2004).

\section{REFERENCES}

Altubas, Y., L. Evans and P. Molyneux, 2001. Bank ownership and efficiency. J. Money Credit Bank., 33: 926-954.

Amihud, Y. and J. Kamid, 1979. Revenue Vs profit maximization: Differences in behavior by the type of control and by market power. Southern Econ. J., 45: 838-846. http://www.jstor.org/stable/1057481

Anderson, E.W., C. Fornell and D.R. Lehmann, 1994. Customer satisfaction market share and profitability: Findings form Sweden. J. Market., 58: 53-66. http://www.jstor.org/stable/1252310

Baker, M.J., C.D. Black and S.J. Hart, 1988. The competitiveness of British industry: What really makes the difference? Eur. J. Market., 22: 70-85. DOI: 10.1108/eb027339

Barros, C.P. and M. Athanassiou, 2004. Efficiency in European seaports with DEA: Evidence form Greece and Portugal. Maritime Econ. Logist., 6: 122-140. DOI: 10.1057/palgrave.mel.9100099 
Barros, C.P., 2003. The measurement of efficiency of Portuguese seaport authorities with DEA. Int. J. Trans. Econ., 30: 335-354.

Barros, C.P., 2005. Decomposing growth in Portuguese seaports: A frontier cost approach. Maritime Econ. Logist., $\quad 7$ : 297-315. DOI: 10.1057/palgrave.mel.9100140

Barros, C.P., 2006. A benchmark analysis of Italian seaports using data envelopment analysis. Maritime Econ. Logist., 8: 347-365. DOI: 10.1057/palgrave.mel.9100163

Baumol, W.J., 1959. Business Behavior, Value and Growth. New York.

Berger, A., 1995. The profit-structure relationship in banking-Test of market-power and efficient structure hypothesis. J. Money, Credit and Bank., 27: 404-431. http://www.jstor.org/stable/2077876

Brown, M.D. and S. Laverick, 1994. Measuring corporate performance. Long Range Plann., 27: 89-98. DOI: 10.1016/0024-6301(94)90059-0

Charnes, A., W.W. Cooper, A. Lewin and L. Seiford, 1994. Data Envelopment Analysis: Theory, Methodology and Applications. Kluwer Academic Publishers, Boston, MA., ISBN: 0-7923-9479-8, pp: 34.

Chlomoudis, C.I., 2006. Port Planning in the Modern Port Industry. J and J Hellas, Piraeus, Greece.

Chlomoudis, C.I., P.L. Pallis, S. Papadimitriou and E.S. Tzannatos, 2007. The linearization of maritime transport and the island regions in EU evidence from Greece. Eur. Trans., 1-15.

Coto Millan, P., J. Banos Pino and A. Rodrigues Alvarez, 2000. Economic efficiency in Spanish ports: Some empirical evidence. Maritime Policy Manage., 10.1080/030888300286581

Cullinane, K., D.W. Song, P. Ji and T.F. Wang, 2004. An application of DEA windows analysis to container port production efficiency. Rev. Network Econ., 3: 184-206. DOI: 10.1016/j.tra.2005.07.003

Cullinane, K.P.B. and D.W. Song, 2003. A stochastic frontier model of the productive efficiency of Korean container terminal. Applied Econ., 35: 251-267. DOI: 10.1080/00036840210139355

Doyle, P., J. Saunders and V. Wong, 1992. Competition in global markets: A case study of American and Japanese competition in the British market. J. Int. Bus. Stud., 23: 419-442. DOI: 10.1057/palgrave.jibs.8490273

Dunshire, A., K. Hartley and D. Parker, 1991. Organizational status and performance: Summary of the findings. Public Admin., 69: 21-40. DOI: 10.1111/j.1467-9299.1991.tb00780.x
Field, A., 2005. Discovering Statistics Using SPSS. 2nd Edn., Sage Publications, London, pp:122-125.

Fitzerald, L., R. Johnston, S. Brignall, R. Silvestro and C. Voss, 1991. Performance Measurement in Service Businesses. CIMA, Unwing Brothers, ISBN: 0-948036-78-8, pp: 320.

Hall, W.K., 1980. Survival Strategies in a Hostile Environment. Harvard Business Review, pp: 75-85.

Hooley, G.J. and D. Jobber, 1986. Five common factors in top performing industrial firms. Ind. Market. Manage., 15: 89-96. DOI: 10.1016/00198501(86)90049-0

Liu, Z., 1995. The comparative performance of public and private enterprises. J. Transport. Econ. Policy, 29: 263-274. http://www.jstor.org/stable/20053084

Lopez, R.C. and N. Poole, 1998. Quality assurance in the maritime port logistic chain. Supply Chain Manage., 3: 33-44. 10.1108/13598549810200915

Maritime Transport Policy, 2007. European Commission. http://ec.europa.eu/transport/maritime/index_en.htm

Marris, R.L., 1964. The Economic Theory of Managerial Capitalism. The Free Press of Glencol, Macmillan, London, New York, pp: 348.

Martinez-Budria, E., R. Diaz-Armas, M. NavarroIbanez and T. Ravelo-Mesa, 1999. A study of the efficiency of Spanish port authorities using data envelopment analysis. Int. J. Trans. Econ., 26: 37-253. DOI: 10.1007/978-3-7908-1765-2

Melendez-Hidalgo, J., P. Rietveld and E. Verhoef, 2007. On the change in surpluses equivalence: Measuring benefits from transport infrastructure investments. Eur. Transport. N., 36: 107-140. http://www.istiee.org/te/papers/N36/06\%20melend ez\%20107-140.pdf

Notteboom, E.T., 2004. Container shipping and ports: An overview. Rev. Network Econ., 3: 86-106. http://www.rnejournal.com/artman2/uploads/1/nott eboom-RNE_june_04.pdf

Pallis, A.A. and G.P. Tsiotsis, 2008. Maritime interests and the EU port services directive. Eur. Trans., 38: $17-31$.

http://www.istiee.org/te/papers/N38/38_PallisTsiot sis.pdf

Pantouvakis, A., C. Chlomoudis and A. Dimas, 2008. Testing the servqual scale in the passenger port industry: A confirmatory study. Maritime Policy Manage., 35: 449-467. DOI: 10.1080/03088830802352095

Park, P.K. and P. De, 2004. An alternative approach to efficiency measurement of seaports. Maritime Econ., 6: 53-69. DOI: 10.1057/palgrave.mel.9100094 
Porter, M., 1980. Competitive Strategy. Free Press, New York, ISBN: 0684841487, pp: 191-214.

Roll, Y. and Y. Hayuth, 1993. Port performance comparison applying Data Envelopment Analysis (DEA). Maritime Policy Manage., 20: 153-161. DOI: 10.1080/03088839300000025

Rust, R., A. Zahorik and T. Keiningham, 1995. Return On Quality (ROQ): Making service quality financially accountable. J. Market., 59: 58-70. http://balrog.ai.wu-wien.ac.at/ j0350354/ap/out6.pdf

Rust, R. and A. Zahorik, 1993. Customer satisfaction, customer retention and market share. J. Retail., 69: 193-215. DOI: 10.1016/0022-4359(93)90003-2

Sink, D.S. and T.C. Tuttle, 1989. Planning and Measuring Your Organization of the Future. Industrial Engineering and Management Press, Norcross, GA., ISBN: 0898060907.

Siomkos, G., 2004. Strategic Marketing. 2nd Edn., Stamoulis Publication, pp: 35.

Speed, R. and G. Smith, 1993. Customer, strategy and performance. Int. J. Bank Market., 11: 3-11. DOI: 10.1108/02652329310039609

Suykens, F., 1986. Ports should be efficient (even when this means that some of them are subsidized. Maritime Policy Manage., 13: 105-126. DOI: 10.1080/03088838600000055
Talley, K.W., 2006. An economic theory of the port. Port Econ. Res. Trans. Econ., 16: 43-65.

Tongzon, J.L., 1995. Determinants of port performance and efficiency. Transport. Res., 29: 245-252.

Wang, T. and K. Cullinane, 2006. The efficiency of European container terminals and implications for supply chain management. Maritime Econ. Logistics, $\quad 8$ : 82-99. DOI: 10.1057/palgrave.mel.9100151

Wilder, P.R., 1981. Port pricing and investment policy for developing countries. J. Econ. Literat., 19: 609-611.

Wright, M., 1985. Auditing the efficiency of the nationalized industries: Exit the controller and auditor general. Public Admin., 62: 95-101. DOI: 10.1111/j.1467-9299.1984.tb00547

Yarrow, G.K., 1973, Managerial utility maximization under uncertainty. Economica, 40: 155-173. http://www.jstor.org/stable/2551777 